УДК 821.163.41.09 Караџић, В. С. https://doi.org/10.18485/msc50.2019.1.ch48

\author{
Душан Иванић
}

\title{
АУТОРСКИ ГЛАС У СРПСКИМ НАРОДНИМ ПРИПОВИЈЕТКАМА ВУКА КАРАЏИЋА
}

\begin{abstract}
Појмом ауторски глас означава се стилско-реторички траг Вуковог (индивидуалног) учешћа у текстовима српских народних приповиједака. У богатој лепези ауторских гласова Вуковог опуса глас приповједача и стилизатора народних приповиједака, настао у „намјештању ријечи”, један је од најважнијих гласова српске поетике приповиједања и српског приповједачког стила. Вукова ауторска индивидуалност у стилизацији народних приповиједака (посебно оних које пише по сјећању) потврђује се блискошћу стилу његове преписке и хроничарског причања.
\end{abstract}

Кључне ријечи: Вук, ауторски глас, индивидуални стил, еквивалентност, поетика приповиједања.

1.

У овом излагању појам глас означава стилско-реторички лик по којем се препознаје Вуково учешће у ауторству текстова српских народних приповиједака. Вук је већ у предговору Мале простонародюе славеносербске пјеснарице (1814), потом у критикама, полемикама и другим дјелима отворио спектар својих гласова, условљених жанром и природом саопштења: једним гласом само посредује, биљежи туђу ријеч, као пописивач и скупљач („готово скупити”); другим обликује текст „намјештањем ријечи": глас приповједача и стилизатора народних приповиједака, један од најважнијих у полифонији Вукових гласова; трећим описује локалитете, обичаје, друштвене прилике и установе међу Србима (глас географа, етнографа, социолога); глас тумача ријечи (лексиколог) мијеша се с претходним гласом и отвара често према гласу приповједача, пошто извјесне ријечи имају значење само у одређеној краткој шаљивој причи, пословици, загонетки, изразу; један скуп гласова долази од Вука полемичара, критичара, аналитичара-коментатора (у предговорима, критикама, трактататима-посланицама, полемикама); шестим се гласом 
приповједају устаничка збивања и биографије устаника (- и тај глас је заправо скуп гласова, од описа и ауторског коментара до анегдотског причања и цитирања туђих гласова); седмим се кодификују граматичка, ортографска или текстолошка питања; осмим гласом Вук пише приватна писма, често стилски синкретична (могло би се рећи да у фрагментима садрже све побројане гласове), пошто се у писмима расправљају језичка, правописна и књижевна питања али и приповиједа о сусретима, догађајима, људима и приликама; девети је глас преводиоца, прилагођен стилско-језичким захтјевима оригинала (у распону од простонародног приповиједања, нпр. књижевне приповијетке које Вук преводи у Даници, до новозавјетне реторике).

С обзиром на тему овог рада, ауторским гласом се назива индивидуализован стилско-реторички слој Српских народних приповиједака, нарочито у збирци из 1821. године. Тај је слој Вуков (све је приповијетке писао по свом сјећању) само у нешто мањој мјери него у његовим историографским, полемичким и сл. текстовима, иза којих није било чврсте традицијске (фолклорне) подлоге, већ животна стварност и свједочанства о њој. Утолико је двогуби атрибут, „Вукова народна приповетка” (Поповић 1968: 111), можда најједноставнија и најтачнија назнака природе ове збирке и оних приповиједака које је писао такође по сјећању, а не по рукописима скупљача и записивача („Пепељуга” и „Међедовић” у збирци из 1853. године): те су приповијетке Вукове по писаном облику, а народне (усмене) по грађи и начину којим је та грађа наслијеђена.

О Вуковом усменом приповједачком дару свједоче различити извори (Ј. Грим, И. И. Срезњевски и др.). То се потврђује и у текстовима који су се тицали непосредног искуства, у предочавању динамике збивања и појединостима животне стварности (нарочито у преписци). О томе први научно проговара Платон Кулаковски поводом Вукових историјских списа („сјајан приповедачки дар”, „живост његовог приповедања”, „епски тон”, Кулаковски 1987: 81). Послије чланка Слободана Јовановића (Гласник Професорског друштва, 1938: 34), то постаје опште мјесто у изучавању претежно оне Вукове прозе која је неспорно његовог пуног ауторства (историографски, биографски, етнографски списи, писма). О томе су писали Андрић, потом Драгиша Живковић, Миливој Павловић, Миодраг Поповић, Радован Самарџић и др. Међутим, кад је ријеч о издању Српских народних приповиједака, одлучујући рез је направио Миљан Мојашевић, студијом „О Вуковој стилизацији српских народних приповиједака" (1953) (Немачко-југословенске књижевне везе, 1974. године). Он је устврдио да у Вуку имамо „књижевника и једног од најистакнутијих, ако не и најистакнутијег творца и српске уметничке прозе”. Уз 
то је на трагу идеје да је стил Српских народних приповиједака - Вуков стил (174), а да је он „од разних стилова правио један, јединствен стил народне приповетке”. И по проф. Мирославу Пантићу, у поговору Cpnским народним приповијеткама, за Караџића записивача може се рећи „сасвим слободно: и приповедача” (наше подвлачење), који је „из записа својих сарадника и из личних сећања [...] градио прекрасно предиво свог приповедања” (1988: 381), а да је то истовремено „умеће, вештина и дар усменог приповедања" (Пантић 1988: 472).

Ово - „и приповедача”, „предиво свог приповедања” - тежиште је нашег излагања: уз оков записивача, стилизатора и редактора готових, наслијеђених усмених творевина, Вуку Караџићу се ставља и оков зачетника фолклорног стила (и нормативног језика српске прозе уопште). ${ }^{1}$ Наиме, Вук се ослања на грађу која је до њега допрла усменим путевима, али не прича ни себи ни кругу слушалаца око себе, већ прије, обраћа се читаоцима. У својим пословима он иде ка рјешавању општијих питања: дати српску граматику (стабилизовати књижевни језик), скупити народне пјесме, пословице, описати обичаје, саставити рјечик српског језика, створити општи народни језик (рекли бисмо данас - стандардни језик или језички стандард), превести Нови завјет на ниво „простонародног језика". Узевши све те циљеве укупно, значило је утемељити српску националну културу на најширој домаћој подлози. Међу таквим најопштијим циљевима био је и - доћи до таквог стила и до језичког стандарда у фикционалној, приповједачкој прози. Као што се надао, с првим текстовима које је објавио 1814, да ће се створити ауторска поезија „по вкусу и по начину рода свога" (у предговору Мале простонародюе славено-сербске пјеснарице (СДВК, I); касније ће, у предговору дјелу Луке Милованова, прецизније говорећи, истицати да би најбоље било да се народне пјесме „узму за темељ и за углед учене наше поезије” (СДВК); тако ће српским прозаистима предлагати Грађу за леп српски роман на основама народних балада и предања (СДВК, VIII), а стилизацијом усмених приповиједака (у распону од кратке шаљиве приче до бајке) давао је образац за ауторску приповијетку, врсту која у српској књижевности тада још нема национални лик, већ се посрбљују туђе творевине.

${ }^{1}$ Овдје би требало ставити напомену, уз синтагму „зачетник фолклорног стила". Примјера фолклорног стила прије Вука у новој српској књижевности има доста (а има га и у старијој традицији), нарочито у Доситејевим дјелима из свих периода његовог стваралаштва: потврђују га и рукописи Гаврила Стефановића Венцловића и др. Кад се Вук издваја, ријеч је о континуитету који с Вуком почиње и од њега се разгранава као једна од доминанти писане прозе. 
Став фолклориста да „написан текст усмене приповијетке, који упознајемо читањем, не функционира више као усмена приповијетка” и да је „преласком у други медиј припао ... писаној књижевности” (Бошковић Стули 1983: 139), кад се ради о Вуку, још је сложенији и можда тачнији: то није био технички, механички прелаз из једног система знакова у други, из усменог у писани медиј, већ преобликовање меморисаног знања или меморијских трагова у текст, процес који се одвија у мучном послу намјештања и премјештања ријечи и уређивања композиције, уза све то с циљем да буде образац („углед”) за писани текст, за ауторску приповијетку. Вук располаже наслијеђеном фабулом и сижејним чиниоцима, док све друго - избор и распоред ријечи, синтакса, интензитет односа између дијелова реченице и композиције, приповједачке перспективе - настаје током писања, гдје се (можда у вишеструким покушајима) бруси, чисти, преправља и поправља потенцијал запамћеног текста и отвара према дотле неутврђеном облику.

2.

Уважавајући што је о томе писано, од Љубомира Стојановића, Петра Скока, Миљана Мојашевића, Миливоја Павловића, Миодрага Поповића, Мирослава Пантића до Наде Милошевић-Ђорђевић и Снежане Самарџије, покушаћемо да препознамо Вуков ауторски глас, прво, у текстовима које он пише тако да буду углед народног језика у прози - образац за приповиједање на српском језику. (Овдје је важно нагласити да Вук мисли на приповиједање у ауторској књижевности, а не у фолклорном, усменом приповиједању.) Друга је ствар што су Вукове Српске народне приповијетке узимане као образац за записе из живог фолклора и што су оне у међувремену продрле међу усмене приповједаче, који су већ постали читаоци. ${ }^{2}$ Друго, уважавајући општа својства приповиједања у усменој традицији, дакле и у Српским народним приповијеткама, или у записима других скупљача и носилаца усменог знања, да издвојимо индивидуализоване црте у Вуковом издању. Треће, да потврђивање тих црта изведемо поређењем Вукових текстова не само жанровски различитих, већ различитог степена ауторства. Вук описује предмете и

2 Као примјер може се узети расправа П. Поповића, „Српске народне приповетке и њихове збирке” (Поповић 1939: 111-125), гдје се Вук не узима само као образац у техници скупљања („загледати у Вука, и у њему гледати образац”, 124), већ и језика (Вукове приповијетке су испричане „дивним језиком и стилом" [111]). 
локалитете, процесе и догађаје, личности у промјенама и испољавањима карактера: то претпоставља тачно опажање слиједа збивања и распореда ствари (нпр. описи обичаја и одјеће), хијерархизацију, повезивање радњи, описа и коментара. Четврто, један круг Вукових текстова настао је с високим степеном спонтаности и непосредности исказа: такав је највећи дио његове приватне преписке, гдје има писама са главним цртама његовог личног, ауторског стила (описи, коментари, приповиједање, апелације, карактеризације људи и прилика). Стил тих писама је незаобилазан аргумент у одређивању природе Вуковог гласа у збиркама народних приповиједака, гдје је Вук несумњиво настојао да пише онако како се приповиједа у усменој култури и како је и сам знао приповиједати.

3.

Што је за основни став овог излагања важно, у вријеме настајања прве збирке (1821) иза Вука је несистематично, непотпуно, али ипак класично школовање; такође кључни граматички и лексикографски текстови, описи прилика међу Србима и у Србији, велик број писама, критика и полемика (чак намјера да ове објави као књигу под насловом Забавник за српске списатеље). Отуда дискурс упамћених и за објављивање приређених народних приповиједака прима извјесне црте и поступке својствене писаном стилу, односно Вуковом дотадашњем списатељском искуству.

Међу тим цртама најупадљивија је сложена реченица, уз честе партиципске конструкције, и уз гомилање описних и приповједних информација. Уз то је уочљив брижљив однос према ритму радње, пошто се то лакше у писму надзире него у усменом приповиједању. Оваквом поступку одговарају, нпр. у приповијеци о животињама Међед, свиға и лисица, истовјетне синтаксичке конструкције („Узораше, посијаше. Дође жетва. Сташе се разговарати, како ће пожети”, „Пожеше и снопље повезаше. Сад се сташе разговарати како ће да вршу”, „Овроше. Међед жито подијели, али га не подијели право”). Ово досљедно понављање у промјенљивим ситуацијама разликује текстове збирке од живе, непосредне усмене ријечи, односно од усменог приповиједања, које се обично не враћа на већ речено и не може да контролише стил као писани текст. Осим тога, Вукова реченица често прелази у комплекс реченица, близак периоду (ако бисмо узели одговарајући термин антикне реторике); реченични крешендо у завршецима, карактеристичан управо за приповијетке писане по сјећању, постаје карактеристичан и за обраде туђих записа, нпр. оних које су настале на Механџићевом предлошку (завршетак приповијетке 
„Ђаво и његов шегрт”). ${ }^{3}$ Такав је и дуг завршетак шаљиве приче-параболе, „Бевојка, удовица и пуштеница”, у набрајању, варирању и тумачењу, састављен од десетак краћих реченица повезаних једном замисли; ${ }^{4}$ такође се може навести завршетак приче о животињама „Међед, свиња и лисица”: „Свиња се уплаши, па рукне и скочи, те нада у поток; а мачка се препадне од свиње, па нада уз крушку, а међед помисли да је она већ свињу удавила, па иде сад на њега, па од страа падне с крушке на земљу, те се разбије и цркне; а лисици остане све жито и слама.” Таква конструкција је једно од најопштијих обиљежја Вуковог приповиједања и у историјским и биографским списима о српским устанцима и устаницима, гдје је лични ауторски статус неспоран, често и у писмима.

4.

Еквивалентност оваквих конструкција у текстовима усменог поријекла и текстовима заснованим на историјском и личном искуству поставља њихово стилско-смисаоно језгро изнад жанровских расјелина. Вук воли да ређа и при томе уноси често смисаоно повезане разлике. Нпр. расуло Јадрана (у Првој години српског војевана на даије) предоча-

${ }^{3}$ Навешћемо Механџићев запис (у транскрипцији на савремено писмо) и Вукову редакцију (СНП 1953: 73, 523).

„Кад дође време цар моли кћер да му да прстен; она плачући удари ш њим од земљу; таки се проспе проја силна по земљи, а онај слуга створи се врабац па почне купити проју по земљи што брже. А једно зрно откотрља се цареву чизму. А цар то гледа зачуђен у мисли шта је то кад то све врабац покупи сву проју. А оно зрно што је било под царевом чизмом, створи се мачак па скочи на врапца и удави врапца." (523)

„Кад се наврше три године дана, дође цар ка кћери својој, пак је стане молити да му да прстен; онда она као срдито баци прстен на земљу; прстен прсне, а од њега се проспе ситна проја, и једно зрно откотрља се под цареву чизму; а слуга се у један пут створи врабац, па на врат на нос стане проју зобати и кад сва зрна позобље, пође да и оно последње испод цареве чизме кљуне, али од зрна у један пут постане мачак па врапца за врат."

${ }^{4}$ У коментару загонетног савјета „премудрога” Соломуна неодлучном младожењи, старац каже: „Е мој синко! није то премудри ништа онако рекао: ако узмеш ђевојку, ти знаш, т. ј. она ће држати, да ти све знаш боље од ње, па ћете слушати какогођ ти оћеш; ако узмеш удовииу, она зна, т. ј. она је већ једном била жена, па сад мисли све да зна; зато неће те ћети слушати, него ће све ћети да ти заповиједа; ако ли узмеш пуштенциу, иувај се мога коюа (па тебе штапом преко ногу), т. j. чувај се да те не ожеже онако, као што је и првог мужа ожегла. (СНП 1853: 22) 
ва се мноштвом глагола: неко заплијенио (котао) па однио, уватио (краву или кобилу) па одвео дома; неки купио па отишао да продаје; некоме се досадило, па отишао да жье жито и гледа љетину... (СДВК, VIII). И кад преноси народне приче, Вук радо набраја радње („па на подне отиде Турчин да препне и напоји коња", Еро с онога свијета), стварајући, између осталог, увјерљиву подлогу за заплет (неколике радње трају толико дуго да омогућују Ери превару и бјекство). Вук држи до детаља и као изврстан познавалац народног језика (ријечи и фразеологија), и познавалац патријархалног живота, али то знање се искоришћава и као основа приповједачке мотивације. Нпр. у „наопакој” слици стварности шаљиве Лажи за опкладу свијет се гради супротно односима између ријечи и могућности, но усклађено на „наопаком” нивоу са стварним приликама патријархалног живота: причалац узјаши пчелца, а пијевца поведе у поводу (као да се ради о два коња); кад буде преко мора, пукне му упрта на торби пуној проса, које се проспе у море; пијевцу метне сијена, а пчелца пусти да nace; у једном моменту пак „ударила киша, па дошло море” итд.

Упркос разликама (рашчлањивању по жанровским групама), у Вукову стилу се назире заједничко језгро: у врсти сликовитости својствене ратарско-сточарској култури; у учесталости једноставних облика (пословица, анегдота, примјер, поређење, парабола, фразеологизам) као многоструко функционалног средства у предочавању прилика, личности и догађаја, или пак у изобличавању противника (у полемикама), ${ }^{5}$ до коментара као средства повезивања појединачног случаја и општељудског искуства.

Нећемо се упуштати у питање шта је старије у Вукову опусу. Први његов текст („као писмо Карађорђу”) није до данас пронађен; други је предговор Малој простонародюој славеносербској пјеснарищи, с јаким упућивањем на временске, мјесне и ситуационе моменте и с честим и важним парентезама (негдје личним, негдје општим, стављеним редовно у заграду); убрзо у његове предговоре улазе као фусноте, напомене и кратке приче или легенде (такође облици парентезе); Српски рјечник је већ каталог основних Вукових тема или жанрова - именовање обичаја, обреда, установа (школа, намастир - манастир и др.), вјеровања, локалитета; приповиједање (вјеровања, предања, приче из живота, шаљиве приче), портрети (фрагменти), догађаји (фрагменти) - од којих свако има елементе особене стилизације, а између тих тематских и жанровских разлика очитују се стилско-реторички додири, јаче или слабије везе.

${ }^{5}$ Уп. Д. Иванић (1990: 60), гдје се истиче да Вук једноставним облицима и фолклорног и ауторског поријекла даје несумњив метатекстуални смисао. 
Одавно је речено да је Вук изградио свој приповједачки стил, односно уобличио „једну базу народског фолклорног стила”, дао „свој стилистички тип изражаја” (Павловић 1964: 69). Та околност или та чињеница не пориче чисто ауторски, индивидуални статус таквог стила, већ га само поставља у одређену традицију. „Вук је у овом поступку исто толико индивидуалан колико је индивидуалан и сваки народни усмени приповедач - интерпретатор, али мање него приповедач стваралац", констатује Нада Милошевић Ђорђевић (2002: 108). Хтјели смо, међутим, рећи да је Вук индивидуалан у већем степену него прави усмени приповједачи, условљено укупном његовом списатељском дјелатношћу и циљевима које је поставио свом раду. У издањима народних приповиједака тај степен индивидуалности постаје препознатљив корак на путу стварања српске ауторске (и како се, донекле неадекватно каже - умјетничке) приповијетке.

Фолклорни тип стила се појавио, разумије се, прије Вука, и у рукописним (поменимо Јеротеја Рачанина или Гаврила Стефановића Венцловића), и у штампаним изворима (дјела Доситеја Обрадовића носе многобројне трагове усмене традиције приповиједања, већ у његовим Буквицама, насталим крајем 60-их година 18. вијека, а не мање у радовима објављеним послије 1783. године). Вук је, међутим, поменутом стилу дао жанровску динамику, стабилне црте и, чак, стилске формуле, које често прелазе у манир. Нпр. у невеликој причи Лаж за опкладу конструкција „Кад..., а то” („Кад тамо, а то двије срне скачу на једној нози”) употребљена је 15-ак пута. Та конструкција носи извјесну експресију изненађења (а како је ова приповијетка пуна невјероватних стања и неочекиваних догађаја, до сусрета с Господом који дроби хљеб у вруће млијеко, њена учесталост неће бити случајна).

Међу изразито индивидуализованим обиљежјима Вуковог приповједачког стила је непосредна експресија, уживљавање у ситуацију, често пренесену слободним неуправним говором („Како би он, царски син, узео говедарску кћер, код толики други царски и краљевски кћери итд.”); уз то иду повремена активирања позиције другог лица („али оћеш!”), која као да из приповједачке перспективе иронизују узалудност јунакове намјере. Нека од тих рјешења су фолклорног поријекла (могу се наћи код Доситеја Обрадовића), али у Вука као да постају манир: туђе ријечи се радо скраћују (Пипер 1988: 213), таки и таки чоек, из тога града, таког и таког, ту и ту, из тога и из тога итд.; овај поступак се, као што је утврдио проф. Пипер, налази у Вуковој преписци и другим његовим списима, мада рјеђе него у народним приповијеткама (Пипер 1988: 215). Њиме се, осим економичности (избјегава се епско понављање), сугерише небитност тачног податка или 
се приповједач ослобађа опсцених и неприличних ријечи („Тамо њима то и то”, „Тамо оне оваквице и онаквице”).

Да је Вук брзо дошао до свог стила, између осталог свједочи одредница ОБИЛ (у СР, 1818), у предању о Милошу Обилићу. На малом простору сажимају се стилска тежишта Вуковог фолклорног приповиједања: учестале временске реченице, динамичан распоред глаголских облика и пут ка сложенијим реченичним конструкцијама (презент, перфект, партицип садашњи у контакту са перфектом) („Кад дођу на оно мјесто, а то дијете код неколико својих оваца ударило своју сјекиру у кладу, па легло на леђа те спава”); потом уживљавање приповједача у ситуацију („Кад то види цар, зачуди се, па пружи руку с коња да му узме сјекиру, али оћеш! не може да је извади из кладе"). Сличне конструкције ће се понављати касније, у приповијеци Еро с онога свијета (1821, прештампано 1870. године): „Онда Турчин потрчи, на врат на нос к воденици; кад тамо, али оћеш! Еро узјао коња па отишао без трага, а Турчин савије шипке, па пјешице к жени." (Подвлачења наша, СДВК, III: 24, 268).

Прва у збирци из 1821, Зла жена, такође има нека од сталних обиљежја Вуковог приповједачког стила: јаке временске границе у фазама радње; паралелизми, понављања, партиципске конструкције (доказујући, идући, стрижући, не гледајући, и не надвирујући се...); неочекивани упади у вријеме збивања из времена приповиједања и идентификовање с перспективом лика („Кад већ уже прикупи до краја, али има шта виђети", 17); такође мјеста појачавања експресије, кад глас приповједача уступа гласу лика („Па то твоја жена! И ти могао с њом живити! И опет дошао да је извадиш!”); повремена рационализација бајковитог свијета („ово су они тако говорили, да нико други није могао чути ни разумјети, осим њи двојице"). Уз ово иду прелази са управног на слободни неуправни говор (и обрнуто), дискретне мотивације; Вукова склоност комичним исходима и не мање вртоглавим, вратоломним окончањима радње (Зла жена, Лаж за опкладу, Међед, свиға и лисица). То није више глас приповједача који слиједи предају или је понавља уз варијације, већ оног који се уједначено држи извјесног круга својих поступака.

О постојаности Вуковог приповједачког гласа (можемо рећи: поступка) свједоче писма из периода кад су настајали његови главни списи и прве приповијетке. Лукијану Мушицком, 15. децембра 1818, овако пише о аудијенцији код аустријског цара (подвлачења наша). (Узгред речено, иза свега што говори осјећа се уживање у приповиједању.)

Кад дођем у јутру у 7 сати у кабинет, а то у једној соби чекају више од 100 људи и жена; помислим ја у себи: кад ћемо ми сви добити ред да 
говоримо с царем, зашто сам мислио да ћемо ићи к њему један по један, као дуовнику на исповијед; кад уђемо у једну велику салу па станемо у реду унаоколо, док једанпут почеше ђекоји шаптати је ли то цар? Кад jа погледам, а то он зашао редом од једнога до другога те узима прошенија и пита шта је. (СДВК, XX, Преписка, I, 640)

Могли бисмо овоме додати опис пријема код Јохана Волфганга Гетеа или Марије Павловне, и низ других писама, али се тип веза између приповиједања у народним приповијеткама и у овим текстовима не би битно повећао: само се умножавају примјери који потврђују јединство Вуковог приповједачког стила. (Овоме се може додати да је Вук и у преводима приповиједака у календару Даница очувао свој карактеристичан стил. Ти су преводи у тој мјери „народни” да су их неки приређивачи научних издања уврстили у збирке српских народних приповиједака, уп. М. Пантић, 1988: 411-413.)

5.

Поред ових теза о ауторском стилу у Вуковим издањима српских народних приповиједака, ваљало би издвојити с овим повезан књижевноисторијски став. Вук се узима као скупљач и као стилизатор наше народне приповијетке. Он је, међутим, својим издањима поставио темеље српске националне приповијетке, у оном смислу у којему је тај појам одредио Јован Суботић за српске народне пјесме, дајући им атрибут Nationlieder: ${ }^{6}$ Вукове приповијетке су такође постале националне (Nationerzählungen), успостављајући језички, а дијелом и тематско-мотивски темељ ауторској приповијеци, која ће класичне представнике наћи у водећим писцима реализма, све до наших савременика. Вукове збирке (почев од 1821, посебно она из 1853. године, уз Српски рјечник и народне пјесме) имале су непосредан утицај на ауторе фикционалне прозе, на Атанасија Николића, Богобоја Атанацковића, Милорада П. Шапчанина, Јована Грчића Миленка, да не помињемо Стефана М. Љубишу, Милована Глишића или Јанка Веселиновића. Тражећи Вуково мјесто у српској ауторској прози, може се устврдити сљедеће: у најширем смислу ријечи, Вук (потом Даничић и др.) утемељује граматичку норму језику ове прозе, а једном дијелу даје стилску (фолклористички стил), па и тематско-мотивску подлогу.

6 „Србске народне песме нису Volkslieder него Nationlieder, као што су код други народа производи стихотворни најсилнији генија у народу” (Заснивање националне критике 1983: 202). 
Утолико би тврдња Љубомира Стојановића да је Вук творац српске прозе и српског стила била само дјелимично прихватљива, пошто је дуго остала жива, старија од Вука, доситејевска подлога, допирући преко Видаковића и Игњатовића до Црњанског и савременијих прозаика; друго, аутори су сами градили свој стилски репертоар, служећи се подлогом Српских народних приповиједака у одговарајућим жанровским проседеима: упоредити, нпр., Јована Грчића Миленка, Л. Лазаревића и С. Матавуља, сваки од њих потенцијал фолклорног стила искоришћава као дио индивидуалног стила.

Несумњиво је Вук српској ауторској прози дао филолошку норму (залагање за народни језик, граматичке норме), а стилску само фолклорно оријентисаним текстовима. Он је објединио идиом писаног и усменог стила на равни језика. Из те равни (или те норме) српски прозаици су даље ишли за својим осјећањем стилске адекватности. (Довољно је упоредити Јакова Игњатовића и Стефана М. Љубишу, савременике, вуковце, од којих свак иде својим путем.) Прије Вука, његових књига и збирки, фолклорна традиција је у писаној пракси била узгредна, парцијална. C Вуком постаје један од главних чинилаца српске књижевности. У том стапању нису потпуно избрисане линије између једног и другог стила, нити је тај „спој” карактеристика само традиционалних приповиједака (народних), већ се осјећа и у писмима, историјским списима (хроникама), портретима устаника, полемикама и критикама. Слободне везе књижевних стилова (чији је дио постао и фолклорни стил) усталиле су се код наших најбољих писаца, од Љубише или Матавуља до Андрића и аутора 21. вијека.

Додајмо да се у малој збирци Вукових српских народних приповиједака" из 1821. године спојила традиција и индивидуални талент, готово у оном смислу који је тим ријечима дао Томас Стерн Елиот (Елиот 1963: 33-42). Грађа фолклорне прозе, преношена усмено, с Вуком је ушла у писану књижевност и добила јединствен, „вуковски” ауторски израз: оном што је била разуђена пракса усменог приповиједања (разуђена по носиоцима приповједног знања, њиховој језичко-регионалној припадности, жанровима, стилу) Вук је дао уједначен стилско-језички, реторички па и жанровски тон (препознатљив по склоности касније српске прозе „на народну” шаљивим садржајима).

Ове народне приповијетке, писане по сјећању, несумњиво се укључују у српску усмену предају. Оне су, међутим, у том степену индивидуализоване (вуковске) да се не могу разматрати само као дио те предаје. У српској књижевности препознатљиве су по Вуковом имену, а дјеловале су на књижевнике више него текстови икојег другог аутора српске прозе, 
осим Доситејевог дјеловања у првој половини 19. вијека. У том је огроман књижевноисторијски значај тих збирки народних приповиједака и Вуковог ауторског гласа у њима.

\section{ИЗВОРИ}

Сабрана дела Вука Караиића, Просвета, Београд, 1965-1998.

I. Мала простонародна славено-сербска пјеснарииа (1814). Народна србска пјеснарииа (1815). Приредио Владан Недић, 1965.

II. Српски рјечник (1818). Приредио Павле Ивић, 1966.

III. Народне српске приповијетке (1821). Српске народне приповијетке (1853). Приредио Мирослав Пантић, 1988.

VIII. Даница (1826, 1827, 1828, 1829, 1834). Приредио Милорад Павић, 1969.

IX. Српске народне пословице (1849). Приредио Мирослав Пантић, 1965.

Х. Нови завјет господа нашега Исуса Христа (1847). Приредили Владимир Мошин и Димитрије Богдановић, 1974.

XI/1-2. Српски рјечник (1852). Приредио Јован Кашић, 1986.

XII. О језику и книжевности I. Приредио Берислав Николић, 1968.

XIII. О језику и кюижевности II. Приредио Милорад Павић, 1968.

XIV. О језику и књижевности III/1. Приредио Голуб Добрашиновић, 1986.

XV. Историјски списи I. Приредио Радован Самарџић, 1969.

XVI. Историјски списи II. Приредио Радован Самарџић, 1969.

XVII. Етнографски списи. Приредио Миленко С. Филиповић, 1972.

XX-XXXI. Преписка I (1811-1821) - XII (1859-1862). Приредио Голуб Добрашиновић и др., 1987-1998.

Скуплени граматички и полемички списи, књ. 1-3, Београд, 1894-1896.

\section{ЛИТЕРАТУРА}

Анали Филолошког факултета. Вуков зборник: зборник реферата са симпозијума; ур. Р. Лалић, Београд, књ. 4 (1964); 5 (1965).

Андрић 1983: И. Андрић, Сабрана дела, књ. 13: Есеји II, Београд.

Бошковић Стули 1983: M. Bošković Stulli, Usmena književnost nekad i danas, Beograd. Вук Караиић и юегово дело у своме времену и данас, 1988: Научни састанак слависта у Вукове дане, Београд, 17/књ. 1-5. 
Вуков зборник, 1966: ур. Виктор Новак, САНУ: Београд.

Гласник Југословенског професорског друштва, 1983: 18: 4-5, 1937-1938: Вуков двоброј, Београд.

Ђурић 1966: В. Ђурић, Вук о напретку или приступ Вуковој поетици, у: Вyков зборник, Београд, 181-189.

Елиот 1963: T. S. Eliot, Izabrani tekstovi, prev., Beograd.

Живковић 1965: Д. Живковић, Од Вука до Андрића, Београд.

Засниваюе националне критике, 1983: Засниване националне критике, пр. Д. Живковић, Н. Сад - Београд.

Иванић 1990: Д. Иванић, О литерарности дјела Вука Стефановића Караџића, Једноставни књижевни облици у Вукову дјелу, у: Модели књижевнога говора, Београд.

Ивић 1966: П. Ивић, О Вуковом Рјечнику из 1818. године, у: СДВК, II, Београд, 19-187.

Књига о Вуку Караџићу: 1787-1937, Југословенско професорско друштво, Београд, 1938.

Кулаковски 1987: П. Кулаковски, Вук Караиић, юегов рад и значај у српској титератури, прев. Лидија Суботин, пог. Хатиџа Крњевић, Београд.

Милошевић Ђорђевић 2002: Н. Милошевић Ђорђевић, Казивати редом: прилози проучаваюу Вукове поетике усменог стварана, Београд.

О Вуку Каращићу 1968: студије и есеји, Београд.

Павловић 1963-1964: М. Павловић, Стил Вука Караџића, у: ЈФ, XXVI/1-2 (1963-1964), п. о. 1-72.

Пипер 1988: П. Пипер, О цитатској референцијалности, у: НССуВД, 17/3, Београд.

Поповић 1964: М. Поповић, Вук Стеф. Каращић 1787-1864, Београд.

Поповић 1983: M. Popović, Pamtivek: Srpski rječnik Vuka Stef. Karadžića, Beograd.

Самарџија 1997: С. Самарџија, Поетика усмених прозних облика, Београд.

Срезњевски 1970: И. И. Срезњевски, Живот Вука Ст. Карачића, прев. А. Сандић, у Новом Саду: Платонова штампарија.

Стојановић 1924: Љ. Стојановић, Живот и рад Вука Стеф. Караџића, Београд.

Сусрети с Вуком, 1964: Избор и редакција Г. Добрашиновић и Б. Маринковић, Нови Сад. 


\section{Dušan Ivanić}

THE AUTHOR'S VOICE IN SERBIAN FOLK SHORT STORIES

BY VUK KARADŽIĆ

\section{Summary}

The term "the author's voice" marks the stylistic and rhetorical trace of Vuk's (individual) participation in the Serbian folk short stories. In a wide spectrum of author's voices of the Vuk's opus, the voice of a narrator and stylist of the folk short stories created in the "arranging of the words" is one of the most important voices of the Serbian poetics of narration and Serbian narrative style. Vuk's authorial individuality in the stylization of the folk short stories (especially those he wrote according to his memory) is confirmed by the closeness of his correspondence and chronicle narration. 